\title{
Military Rescue Operation for the Hostages Taken by Somali Pirates: Was the Korean Navy's "Daybreak in the Gulf of Aden" Legitimate?
}

Eric Yong Joong Lee*

On January 21, 2011, the Korean navy commandos rescued the twenty-one crewmen abducted and detained by Somali pirates in the Indian Ocean. The pirates captured alive were brought to Korea for trial and the prosecutor's office of Pusan sentenced the leader of the Somali pirate group to life-imprisonment. The other four pirates received imprisonment terms from 12 to 15 years. Regardless of these domestic legal punishments, this rescue operation has raised a few critical international legal questions. The primary objective of this paper is to answer these questions. This research analyzes the international legal characteristics of the Korean Navy's rescue operation. Then, a few case-studies of military rescue operation are carried out in order to justify the Korean Navy's rescue operation. The Korean Navy's rescue operation may be regarded as an act of forcible self-help and realization of existing international legal right.

\section{Keywords}

Somali Pirates, Daybreak in the Gulf of Aden, Forcible Protection of Nationals Abroad, UNCLOS, Self-Defense, Self-Help, Entebbe Raid

* Professor of International Law at Dongguk University, Seoul, Korea; President of YIJUN Institute of International Law. B.A.(U. Washington), M.P.A.(Seoul N. U.), LL.M.(Leiden), Dr.iur.(Erasmus). The views reflected in this article are his own. Readers' comments are cordially welcome. The author may be contacted at: grotian@hotmail.com / Address: 56 Migaro, Kwangin-gu \#302, Seoul 143-825 Korea. 


\section{Introduction}

At the dawn of January 21, 2011, twenty-two commandos of the Republic of Korea ("ROK") Navy's UDT/SEAL began a special operation about 1,300 kilometers off northeast Somalia in the Indian Ocean. Under the codename, "Daybreak in the Gulf of Aden," the purpose of this operation was to rescue twenty-one abducted crewmen of the SAMHO Jewelry, an 11,500-ton oil/chemical tanker which had been hijacked by some Somali pirates six days before. With cover from the Lynx helicopter and the Choi Young, a 4,500-ton destroyer of the ROK's Chunghae (Blue Sea) unit, those commandos raided the hijacked ship and finally rescued all hostages on board composed of 8 Koreans, 2 Indonesians and 11 Burmese. With this 5-hour long special operation, the commandos killed 8 pirates by shooting and captured 5 pirates alive. The captain of the ship was shot by a pirate and immediately taken to a hospital by a U.S. helicopter. There was no human loss in the commando unit. 1

The pirates captured alive were brought to Korea for trial on January 30, 2011 because the third countries in this region such as Oman, Kenya and Yemen, in spite of Korea's proposal for extradition, refused to try them in their countries. The prosecutor's office of Pusan, Korea, filed suits against them for the crimes of ship-kidnapping, assault, maritime robbery, maritime murder attempt, etc. ${ }^{2}$ By way of the proceedings, the Pusan District Court applied the domestic criminal laws (not directly related to piracy under international law) and sentenced the leader of the Somali pirates group to life-imprisonment. The other four pirates received imprisonment terms from 12 to 15 years. 3

Legal punishment against foreign pirates in a domestic court is a very exceptional case in the contemporary world. Just a few cases have been reported so far. 4 This adjudication was realized by the forcible transfer of convicted pirates captured by special raid of the Korean Navy on the high seas. It was mainly based on Article 105 of the United Nations Convention on the Law of the Sea ("UNCLOS") which lays down: "On the high seas, or in any other place outside the jurisdiction of any State, every State

1 Taehoon Lee, Navy rescues all 21 abducted sailors, KoREA TrMES, Jan. 21, 2011 available at http://www.koreatimes.co.kr/ www/news/nation/2011/01/116_80096.html (last visited on Jan. 29, 2012).

2 Jung-ryul Lee, Somali Pirates Case from a Domestic Legal Standpoint (available only in Korean), THE 30TH International Humanitarian LaW Seminar Proc.(Korea Red Cross), Nov. 18, 2011, 56. He was a member of prosecutors in this case.

3 Pusan District Court, Judgment 2011KoHap93 (May 27, 2011). This case was finally adjudicated at the Supreme Court of Korea on Dec. 22, 2011.

4 The Netherlands and the United States tried Somali pirates in their domestic courts in 2009 and 2010, respectively. 
may seize a pirate ship or aircraft, or a ship or aircraft taken by piracy and under the control of pirates, and arrest the persons and seize the property on board.” This general and comprehensive regulation, however, does not specify the measures to seize a pirate ship or aircraft. In particular, military rescue operation would raise a few critical legal controversies due to the probable inconsistency with Article 2(4) of the UN Charter. In addition, it will be questionable whether a piracy-like maritime crime is definitely within the category of piracy under Article 101 of the UNCLOS. 5 Currently, about $80 \%$ of ship kidnapping in the world reportedly happens in territorial waters. Article 101 would not apply to those cases. 6 If the SAMHO Jewelry was hijacked and rescued in the territorial sea, as frequently happened nowadays, the Korean Navy's operation would have infringed the territorial integrity of Somalia. It might also cause the encroachment of sovereignty of Malta, the flag country as well as the commercial damage to the Norwegian ship-owning company. Because quite complicated problems may arise relating to State responsibility under international law, many countries are very prudent or even reluctant to engage in forcible seizures of pirate ships for these reasons. In this sense, the international legal implications of Korean Navy's military operation against the Somali pirates on the SAMHO Jewelry (Daybreak in the Gulf of Aden) should be carefully examined.

The basic characteristic of the "Daybreak in the Gulf of Aden" operation was "forcible protection of (Korean) nationals abroad" with military measure because the crewmen were abducted by armed robbers in a foreign ship. What should be considered most urgently is the legitimacy of the military rescue operation of the hostages detained by pirates in a foreign jurisdiction. Under which grounds should it be lawful? My research will try to answer this question from an international legal perspective.

This paper is composed of five chapters including Introduction and Conclusion. Part II will deal with the doctrines regarding forcible protection of nationals abroad. Part III will analyze the international legal bases of the Korean Navy's special rescue operation. General international law, the UN Security Council's resolutions, and International Convention against the Taking of Hostage will be handled here. Part IV will examine the legal characteristics of the "Daybreak in the Gulf of Aden" operation. This part will compare self-defense with self-help under international law in order to find the legitimate ground of the operation. A few case- studies concerning forcible protection of nationals abroad in the postwar period will be examined for their justification of

\footnotetext{
Infra note 20.

6 For details on Article 101, see United Nations Convention on the LaW of the Sea 1982: A Commentary, vol. 3, 197 202 (S. Nandan \& S. Rosenne eds. 1995).
} 
military rescue operations.

\section{The Doctrinal Approach to the Forcible Protection of Nationals Abroad}

\section{A. Overview}

Use of force has been a common feature in human society. Up until the early 20th century, people did not regard it even as illegal in inter-state relations. The League of Nations tried to achieve international peace and security by accepting the "obligations not to resort to war." The absolute right of the States to go to war, however, was not fully excluded under the Covenant.7 Although the Paris Pact of 1928 on the Banning of War (Kellogg-Briand Pact) embodied the renunciation of war as an instrument of national policy, 8 it was not able to replace the old customary rule on the right of States to the use of force. ${ }^{9}$ Since the end of World War II, however, the use of force has been comprehensively prohibited by Article 2(4) of the Charter, which says: "All Members shall refrain in their international relations from the threat or use of force against the territorial integrity or political independence of any state, or in any other manner inconsistent with the Purposes of the United Nations." The only exceptions to the principle of prohibition of the use of force are 'self-defense' under Article 51 of the Charter and the authorization of the Security Council. 10 The "forcible protection of nationals abroad" is thus in a grey zone.

\section{B. The Debate: Pros and Cons}

The "forcible protection of nationals abroad" has been generally recognized as a kind of self-defense by a group of scholars.11 They contend that this type of protection would not violate the prohibition of the use of force under Article 2(4) because it does not

\footnotetext{
P. MALANCZUK, AKehuRst's Modern InTRoduction to InTERnational LaW 24 (7th ed. 1997).

C. Wallace, Kellogg-Briand Pact 1928, 3 EncYClopedia of PuBlic INT' L L. 236 (R. Bernhardt ed. 1982).

Malanczuk, supra note 7.

U.N. Charter art. 42.

11 T. Ruys, The Protection of Nationals Doctrine Revisited, 13 J. Conflict \& SECURITY L. 235 (2008). For details, see R. Lillich, Forcible Self-Help to Protect Human Rights, 53 IowA L. Rev. 336-337 (1967); J. Paust, Entebbe and Self-Help: The Israeli Response to Terrorism, 2 Fletcher Forum 89-90(1978); L. Henkin, How Nations BehaVe: LaW AND Foreign Policy 145 (2nd ed. 1979); R. Higgins, Problem and Process: International LaW and How We Use It 220221 (1994).
} 
impair the 'territorial integrity' or 'political independence' of a third State, but just rescues nationals from a danger in that country. 12 It is understood as an exercise of the right of self-defense under Article 51 of the Charter. 13 Some of these international lawyers identified nationals with States. Fitzmaurice held that "...the right of selfdefense extends not only to the protection of a State's territory...but equally to the protection of its nationals in foreign territory..." 14 Bowett asserted that: "...protection of the nationals of the State was, in fact, protection of the State itself." 15 They further argued that the UN Charter includes the 'inherent right' of self-defense reflecting the wide-spread pre-existing customary right of self-defense which extended to the protection of nations. 16

Another group of scholars, however, has maintained a different position. They regard the forcible protection of nationals abroad as incompatible with Articles 2(4) and 51 of the Charter. 17 Randelzhofer claimed that "the security or existence of a State is not under threat [even] if its nationals are assaulted in another country." 18 He continues to maintain:

those States that have actually carried out such rescue operations have always refrained from accusing the territorial State of an 'armed attack.' Instead, they have usually referred for a justification to customary law, existing unaffected by Article 51 of [the UN Charter]. However, having regard to the interpretation of Article 51 as an exhaustive regulation which restricts the relevant customary law, this claim is no longer convincing. Therefore, forcible rescue operations for nationals endangered in another country are no longer lawful under the UN Charter.19

12 Id.

13 L. Doswald-Beck, The Legality of the United States Intervention in Grenada, 31 NeTH. InT' L L. Rev. 360 (1984); C. Greenwood, International Law and the United States Air Operation against Libya, 89 West VIRGINIA L. Rev. 941 (1986-1987);

14 G. Fitzmaurice, The General Principles of International Law Considered from the Standpoint of the Rule of Law, RECUEIL DES COURS 172 (1957-II).

15 D.W. BowetT, SELF-Defence In InTERnational LaW 91 (1958).

16 Ruys, supra note 11, at 236.

17 A. Randelzhofer, Article 51, The Charter of the United Nations: A Commentary, vol. 1, 798-799 (B. Simma et al eds. 2001); J. Mrazek, Prohibition on the Use and Trheat of Force: Self-Defence and Self-Help in International law 27 Can. Y.B. InT' L L. 97 (1989); I. Brownlie, The Principle of Non-Use of Force in Contemporary International Law, The Non-Use of Force in International LaW 23 (W.E. Butler ed. 1989); Henkin, supra note 11, at 145.

18 Randelzhofer, supra note 17 , at 798.

19 Id. at 799. 


\section{The Legal Grounds of "Daybreak in the Gulf of Aden" Operation}

\section{A. Anti-Piracy Rules}

The basic legal ground of the Korean Navy's military rescue operation may be found in the anti-piracy rules in the UNCLOS and the Geneva Convention on the High Seas of 1958 ("HSC"). Article 101(a) of the UNCLOS defines "piracy' as "any illegal acts of violence or detention, or any act of depredation, committed for private ends by the crew or the passengers of a private ship or a private aircraft, and directed: (1) on the high seas, against another ship or aircraft, or against persons or property on board such ship or aircraft; (2) against a ship, aircraft, persons or property in a place outside the jurisdiction of any State." 20 If a ship or aircraft is intended by the persons in dominant control to be used for the purpose of committing one of the acts referred to in Article 101 , it is a pirate ship or aircraft. 21

Once identified with piracy, every State is obliged to act against it.22 It is an exception to the long established principles of "freedom of the high seas" or more concretely "flag State jurisdiction" on the high seas. The UNCLOS, in Article 105, grants signatories privilege to fight against piracy as follows: 23

On the high seas, or in any other place outside the jurisdiction of any State, every State may seize a pirate ship or aircraft, or a ship or aircraft taken by piracy and under the control of pirates, and arrest the persons and seize the property on board. The courts of the State which carried out the seizure may decide upon the penalties to be imposed, and may also determine the action to be taken with regard to the ships, aircraft or property, subject to the rights of third parties acting in good faith.

Also, a warship is entitled to visit or engage in hot pursuit of a suspicious pirate ship if it has adequate and objective grounds. ${ }^{24}$ Following the regulations, any State can seize a pirate ship on the high seas and arrest pirates there. Those pirates would be punished

Article 101 includes the following as piracy: (b) any act of voluntary participation in the operation of a ship or of an aircraft with knowledge of facts making it a pirate ship or aircraft; (c) any act of inciting or of intentionally facilitating an act described in subparagraph (a) or (b). See UNCLOS art. 101; HSC art. 15. For details on the definition of piracy under the UNCLOS or the HSC, see Nandan \& Rosenne, supra note 6.

21 UNCLOS art. 103; HSC art. 17.

22 R. Churchill \& A. Lowe, The LaW of THe Sea 209 (1999).

23 See also HSC art. 19. For details, see Nandan \& Rosenne, supra note 6, at 213-216.

24 UNCLOS arts. $110 \& 111$. 
by the court of any State under 'universal jurisdiction.' 25 In spite of such regulations, however, anti-piracy rules laid down at the UNCLOS/HSC could not fully cover the maritime crimes currently committed by Somali pirates. According to the UNCLOS, piracy shall involve two vessels - pirate and victim; attempts by passengers to gain control of ship are not acts of piracy, but hijacking.26 In addition, acts of piracy should be committed on the high seas or in any other place outside the jurisdiction of any State. 27 This regulation has been substituted by the Convention for the Suppression of Unlawful Acts of Violence against the Safety of Maritime Navigation (SUA Convention). The SUA Convention addresses a broader scope of maritime crimes including armed robbery as well as piracy.28 The SUA Convention, nonetheless, also maintains the principle of the high seas, stating that: "This Convention applies to ships navigating or scheduled to navigate into, through, or from waters beyond the outer limit of the territorial sea of a single state." 29 International character, eventually, shall be a mandatory criterion to deciding whether an act of piracy occurred because the territorial sea is "essentially within domestic jurisdiction." Thus, what happens there shall be regarded to be the domestic affairs of the costal State. Considering that the SAMHO Jewelry was hijacked and navigating on the high seas until it was rescued, the Korean Navy's attempt to seize the ship taken by the Somali pirates was in accordance with the international law against piracy including the UNCLOS.

\section{B. The Security Council Resolutions}

Although those who hijacked the SAMHO Jewelry would be categorized as pirates, Article 105 of the UNCLOS does not provide the direct legal ground for the military rescue operation of the Korean Navy. The Security Council resolutions would be thus another legal base for the "Daybreak in the Gulf of Aden" operation.

\footnotetext{
25 For details on the 'universal jurisdiction,' see StePhen Macedo, Universal JuRISDiCTion: National CourTS AND tHE Prosecution of Serious Crimes Under International LaW (2006); Mitsue Inazumi, Universal Jurisdiction in Modern International Law: Expansion of National Jurisdiction for Prosecuting Serious Crimes under

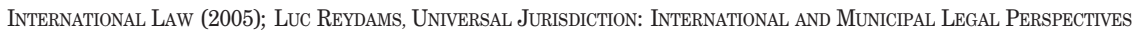
(2004); Madeline Morris, Universal Jurisdiction in a Divided World: Conference Remarks, 35 New England L. REv. 337-361(2001).

26 Churchill \& Lowe, supra note 22 , at 210.

27 UNCLOS art. 101(a).

28 SUA Convention art. 3.

29 Id. art. 4.
} 
Table III-1: Security Council Resolutions against the Act of Piracy and Armed Robbery off the Coast of Somalia

\begin{tabular}{|c|c|c|c|}
\hline Res. No. & Date & Subject & Development \\
\hline 1816 & $\begin{array}{c}\text { June 2, } \\
2008\end{array}$ & $\begin{array}{l}\text { Somali } \\
\text { pirates }\end{array}$ & $\begin{array}{l}\text { - Constitutes a threat to international peace and security } \\
\text { - Enter the territorial waters of Somalia to repress the act } \\
\text { of piracy }\end{array}$ \\
\hline 1838 & $\begin{array}{l}\text { Oct. 7, } \\
2008\end{array}$ & $\begin{array}{l}\text { Somali } \\
\text { pirates }\end{array}$ & $\begin{array}{l}\text { - Continue to take action to protect the WFP maritime } \\
\text { convoys (Res. 1814) }\end{array}$ \\
\hline 1846 & $\begin{array}{l}\text { Dec. } 2, \\
2008\end{array}$ & $\begin{array}{l}\text { Somali } \\
\text { pirates }\end{array}$ & $\begin{array}{l}\text { - Escalating ransom payments are fuelling the growth of piracy } \\
\text { - Sharing Information through bilateral channels } \\
\text { - Urges States parties to the SUA Convention to fully implement } \\
\text { their obligation }\end{array}$ \\
\hline 1851 & $\begin{array}{c}\text { Dec. 16, } \\
2008\end{array}$ & $\begin{array}{l}\text { Somali } \\
\text { pirates }\end{array}$ & $\begin{array}{l}\text { - Invites all States/regional organizations fighting piracy off the } \\
\text { coast of Somalia to conclude special agreements or arrangements } \\
\text { with countries willing to take custody of pirates in order to } \\
\text { embark law enforcement officials("shipriders") }\end{array}$ \\
\hline 1897 & $\begin{array}{c}\text { Nov. 30, } \\
2009\end{array}$ & $\begin{array}{l}\text { Somali } \\
\text { pirates }\end{array}$ & $\begin{array}{l}\text { - Commends the work of the CGPCS to facilitate coordination in } \\
\text { order to deter acts of piracy } \\
\text { - Establish an International Trust Fund to support CGPCS }\end{array}$ \\
\hline 1918 & $\begin{array}{c}\text { Apr. 27, } \\
2010\end{array}$ & $\begin{array}{l}\text { Somali } \\
\text { pirates }\end{array}$ & $\begin{array}{l}\text { - Context the progress being made to implement the IMO } \\
\text { Djibouti Code of Conduct } \\
\text { - Request... aim of prosecution and imprisoning persons responsible } \\
\text { for acts of piracy, and the creation of special domestic chambers } \\
\text { in order to achieve and sustain substantive results }\end{array}$ \\
\hline 1950 & $\begin{array}{c}\text { Nov. 23, } \\
2010\end{array}$ & $\begin{array}{l}\text { Somali } \\
\text { pirates }\end{array}$ & $\begin{array}{l}\text { - Take action under their existing domestic law } \\
\text { - Cooperation with INTERPOL/Europol to investigate } \\
\text { International criminal networks }\end{array}$ \\
\hline 2015 & $\begin{array}{c}\text { Oct. 24, } \\
2011\end{array}$ & $\begin{array}{l}\text { Somali } \\
\text { pirates }\end{array}$ & $\begin{array}{l}\text { - Establishment of specialized Somali anti-piracy court } \\
\text { - Adopt a complete set of counter-piracy law } \\
\text { - Urged states that have not done so to criminalize piracy under } \\
\text { their domestic law }\end{array}$ \\
\hline 2020 & $\begin{array}{c}\text { Nov. 22, } \\
2011\end{array}$ & $\begin{array}{l}\text { Somali } \\
\text { pirates }\end{array}$ & $\begin{array}{l}\text { - Having jurisdiction over anyone who incites or intentionally } \\
\text { facilitates piracy operations } \\
\text { - Take appropriate Actions under the existing domestic law } \\
\text { - Commends INTERPOL for the creation of a global piracy database }\end{array}$ \\
\hline
\end{tabular}

Source: Compiled by the author 
In 2008, the UN Security Council began taking positive action against the acts of piracy and armed robbery in the western Indian Ocean and the Gulf of Aden. In Resolution 1816, the Security Council, regarding the piracy and armed robbery against vessels in the territorial waters of Somalia and the high seas off the coast of Somalia as "a threat to international peace and security" in the region, urged the international society to work together to combat Somali piracy. 30 This resolution asked the States interested in using commercial maritime routes off the coast of Somalia to coordinate their efforts to deter acts of piracy and armed robbery under applicable international law. ${ }^{31}$ Nine resolutions followed concerning Somali piracy. ${ }^{32}$ There are three key elements in these resolutions. First, the Security Council, for the first time in its history, recognized 'piracy' as a grave threat to international peace and security. The Security Council's actions against the Somali pirates thus have been and will be taken under Chapter VII of the Charter. It means that the international community realizes that the Somali piracy represent a very grave threat. Second, in order to stabilize maritime peace and order in this region, the States concerned were encouraged to operate combined armed forces. According to the resolutions, vessels, aircraft and personnel whose primary mission is to conduct antipiracy activities come from different countries and are assigned to those missions as: Operation Ocean Shield (NATO and partner States), Atalanta (EU and partner States), and Combined Task Force 151. Independent missions are also carried out by China, India, Iran, Japan, Korea, Malaysia, and Russia. 33 Third, the operational sector of the combined armed forces has been expanded into the territorial water of Somalia beyond the high seas. Those naval vessels and aircraft were permitted to enter the territorial waters of Somalia and take "all necessary means to repress acts of piracy and armed robbery." 34 This progressive decision of the Security Council is inconsistent with the conventional definition of piracy under international law which covers illegal acts only on the high seas.[Emphasis added] It could be, however, understood that the Security Council is taking more active and efficient measures to cope with the newly arising mode of piracy which would be initiated inside territorial waters.

\section{International Convention against the Taking of Hostages}

Another legal base for the naval rescue operation is the International Convention

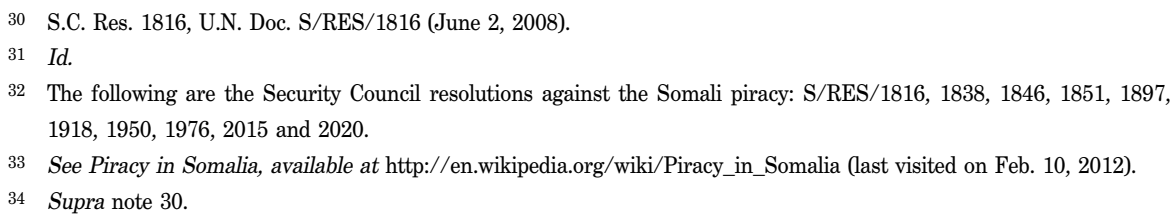


against the Taking of Hostages (Hostage-Taking Convention). ${ }^{35}$ Article 1 of the Convention defines 'hostage-taking' as when an individual "seizes or detains and threatens to kill, to injure or to continue to detain another person in order to compel a third party, namely, a State, an international intergovernmental organization, a natural or juridical person, or a group of persons, to do or abstain from doing any act as an explicit or implicit condition for the release of the hostage." The State party in the territory of which the hostage is held by the offender can take all measures it considers appropriate to ease the situation of the hostage. ${ }^{36}$ States parties should cooperate in the prevention of the offences by taking all practicable measures to prevent preparations in their respective territories. 37

\section{Legal Characteristics the Korean Navy's Rescue Operation}

\section{A. Self-Defense or Self-Help?}

\section{Comparison between Self-Defense and Self-Help}

It is generally accepted that postwar international law outlaws the use of force for the settlement of international disputes. The UN Charter enumerates this principle in Article 2(4). Simultaneously, the Charter provides exceptions to the prohibition of use of force; Article 51 recognizes the "inherent rights [of the member States] of individual or collective self-defense if armed attack occurs." Under the cause of self-defense, resort to force against other nations have been justified since the end of World War II. Could the Korean Navy's rescue operation then be categorized into an exercise of self-defense?

The right of self-defense has been recognized as a fundamental principle of international law. 38 The classical grounds of self-defense may be found in the Caroline case which arose out of an incident in the 1837 Canadian insurrection against the British. 39 When McLeod, a British subject who had participated in the raid, was arrested

G.A. Res. 146 (XXXIV), U.N. GAOR, 34 ${ }^{\text {th }}$ Sess., Supp. No. 46, at 245, U.N. Doc. A/34/46 (1979), entered into force June 3, 1983.

36 Hostage-Taking Convention art. 3(1).

37 Id. art. 4(a).

38 G. Schwarzenberger, The Fundamental Principles of International Law, 87 RecuEIL DES CouRs 195 (1955-I); Malanczuk, supra note 7, at 311ff; B.O. Bryde, Self-Defence, 4 EncYclopedia of Public InT'L L. 212-214 (R. Bernhardt ed. 1982).

39 The Caroline was a ship which was used by a Canadian insurrection group to ferry supplies across the St. Lawrence River. The United States did nothing to do for stopping the ship despite of the diplomatic protest of the British. In 
in the United States three years later and charged with murder in connection with this event, the British contended his immunization due to the ground that the expedition was justified under the right of self-defense. 40

Self-defense requires "necessity, instant, overwhelming, leaving no choice of means, and no moments for deliberation." 41 In addition, the following three conditions are required: (1) immediacy; (2) the absence of alternative means of action; and (3) proportionality.42 Many legal scholars have agreed that hostile acts against a State's nationals abroad can constitute an 'armed attack' giving rise to the right of selfdefense. 43 According to the principle, "an injury to a national of a State is that to the State itself." 44 The Permanent Court of International Justice( "PCIJ") stated in the Mavromatis Case as follows:

It is an elementary principle of international law that a State is entitled to protect its subjects, when injured by acts contrary to international law committed by another State, from whom they have been unable to obtain satisfaction through the ordinary channel. 45

To protect its nationals abroad was recognized as a right of the State as the doctrine of intervention developed to permit a State to take coercive action in cases of 'absolute necessity.' 46 Knisbacher states that the doctrine of intervention should be applied consistently with the Article 2(4) limitations on the right to resort to force as it has been most frequently defended by reference to right of self-defense. 47 The obvious reason for this reliance, he added, is that Article 51 overrides the more general restrictions of Article 2(4).48

Evidence would also be provided by the postwar State practice that supports the

December 1837, a British expeditionary force crossed the river into the U.S. territory and seized the ship. The Caroline was set afire and sent on the final voyage over Niagara falls; two American citizens were killed in this process. Afterwards, diplomatic notes were exchanged and the matter was temporarily closed. For details, see R.Y. Jennings, The Caroline and McLeod Cases, 32 AM. J. INT'L L. 82 (1938).

40 Id.

41 Id. at 89. See also M. Knisbacher, The Entebbe Operation: A Legal Analysis of Israel's Rescue Operation, 12 J. INT'L L. \& Eco. 70 (1977).

42 Id. at $70-71$.

43 Fitzmaurice, supra note 14, at 171-172 (1957-II); J. Fawcette, Intervention in International Law: A Study of Some Recent Cases, 103 RecueIl Des Cours 404-405 (1961-II); Q. Wrights, Intervention 1956, 51 Am. J. INT' L L. 257-272 (1957).

44 Knisbacher, supra note 41, at 75.

45 See Mavromatis Palestine Concessions, [1924] P.C.I.J., ser. A, No. 2, at 12.

46 H. Lauterpact, OpPenheim's International LaW I, sec. 319(8th ed. 1955).

47 Knisbacher, supra note 41 , at 76.

48 Id. 
doctrine of intervention to protect a State's nationals abroad. Belgium advocated sending its troops to Congo in 1960 as follows:

They[Belgium troops] intervened to the extent necessary to fulfill our sacred duty to protect the lives and honour of our nationals; their action was always limited to these specific objectives... 49

When the United States landed marines in the Dominican Republic in 1965, the U.S. permanent representative to the United Nations, Mr. A. Stevenson presented as follows:

Dominican law enforcement and military officials informed our Embassy that the situation was completely out of control, that the police and the Government could no longer give any guarantee concerning the safety of Americans... that only an immediate landing of United States forces could safeguard and protect the lives of thousands of Americans...50

Another noticeable example of discussing self-defense doctrine is the Nicaragua Case. The ICJ, in its judgment, recognized the collective self-defense as 'inherent rights' existing in customary international law. 51 The Court held that the lawfulness of the "response to the attack" is dependent on the "criteria of the necessity and the proportionality of the measures taken in self-defence." 52 Moreover, the Court maintained that the "specific conditions have to be met" for the exercise of collective rights of self-defense 53 to be justified. In the case of the third party intervention, especially, the victim State must request assistance from the intervening State.54 The ICJ did not accept the U.S. justification of "supporting the Contras in their rebellion against the Nicaraguan government" as a valid use of self-defense. 55

Analyzing the abovementioned statements, however, the author has found some difficulties in regarding the Korean Navy's rescue operation in the Gulf of Aden fully as self-defense under international law. The reasons are as follows. First, the rescue

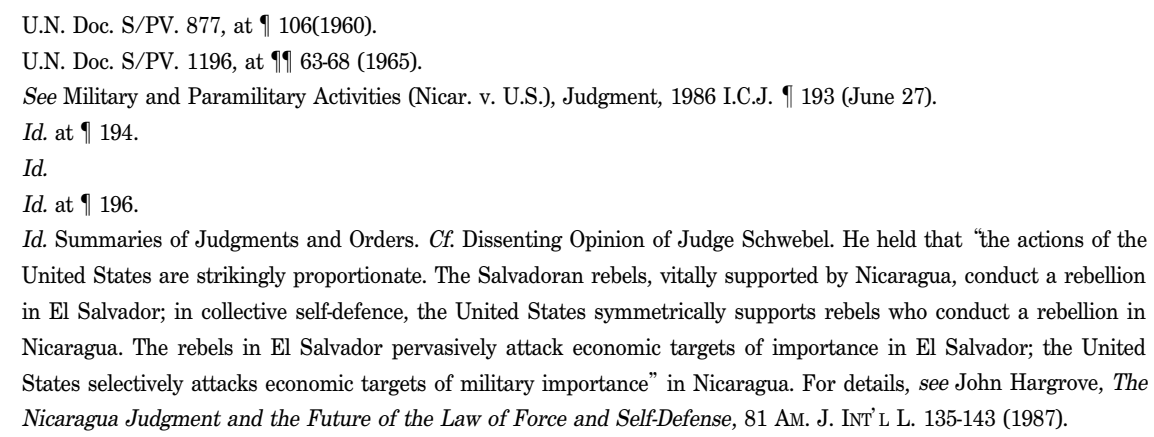


operation occurred six days after the Somali pirates hijacked the ship. Self-defense should be an 'instant' response against the armed attack of the other side. Second, forcible rescue operation was not the only measure to protect the crewmen on board. Customary international law and postwar State practice would not recognize the exercise of self-defense as lawful when any kind of negotiation is going on.56 At that time, both sides - the hijackers and the ship company - were negotiating the terms of release of the crewmen and return of the ship. Third, there had been no preemptive armed attack from the Somali pirates when the Korean Navy's Lynx Helicopter began shooting at the Somali pirates. Kidnapping a ship on the high seas and detaining the crewmen is a definite act of piracy seriously violating of international law. However, it is not 'armed attack' under Article 51 which is the main premise for a State to invoke its "inherent right of self-defense." 57 The Korean Navy might take preventive action prior to the attack from those pirates. Fourth, the hijackers were a private group of pirates from Somalia. The right of self-defense shall be applied to armed conflicts between sovereign nations. 58 If either the Somali government or the Maltese government colluded with the pirates to seize the SAMHO Jewelry, the Korean Navy's armed attack would be an exercise of self-defense in part. No evidence of such collusion has been found yet by any side.

Meanwhile, eight pirates were killed by the Korean Navy's commandos in the course of the rescue operation. Whether this killing was necessary would be debated in relation to self-defense. Those pirates were killed mainly because they resisted the raid of the navy commandos with fatal arms. The minimum number of death would be inevitable in the course of law enforcement action against the heavily armed criminals. The pirates also tried to kill the crewmen; actually a pirate shot the captain of the ship in the abdomen during the operation. The swiftest action should be required for the commandos to suppress the pirates' resistance. In this crossfire, there was no other choice but to kill pirates resisting with arms. No evidence has been reported regarding the navy commandos' unnecessary shot to the pirates who expressed the clear intention of surrender.

Although the "Daybreak in the Gulf of Aden" was a military rescue operation based on the sovereign right of the State for the forcible protection of nationals abroad, it would not fully meet the conditions for self-defense under international law. The alternative justification of the military operation may derive from the "right of self-

\footnotetext{
56 See United States Diplomatic and Consular Staff in Teheran (Iran v. U.S.), Judgment, 1980 I.C.J. ๆ 93 (May. 24).

57 For details on the definition of armed attack, see T. RUYs, 'ARMED ATTACK' AND ARTICLE 51 of the UN ChaRTER (2010).

58 T. R. Krift, Self-Defense and Self-Help: The Israeli Raid on Entebbe, 4 BRooklyn J. INT'L L. 48 (1977).
} 
help." 59 Customary international law recognizes that a "State has the right to use force for the protection of its nationals abroad in situations where the state of their residence is unable or unwilling to grant them the due protection." 60 Self-help may be directed to cases "not attributable to States." 61 When an independent force threatens the rights of a sovereign State, the doctrine of self-help shall be applied instead of that of self-defense. Self-help is a secondary right which arises after a wrong has been committed.62 It is different from self-defense in the sense that the latter is invoked for 'instant' measures of forcible coercion which must be taken in response to the 'present' situation. 63 Selfhelp may aim to create lawful conditions when violations of a State' rights do not occur in the form of an armed attack. 64 The use of forcible self-help can be justified when "such action intends only to protect the lives of the nationals abroad and confines itself to that protection." 65

In the classical period, self-help had the following three-forms: (1) self-defense; (2) reprisal; (3) retorsion.66 Reprisals are "illegal acts undertaken in retaliation against a State to compel it to agree to a satisfactory settlement of a dispute originating in an earlier illegal act done by it." 67 Retorsion is a kind of retaliation in international relations. It occurs when a State feels that "its rights have been violated to the extent that it must respond generally in a legal manner." 68 It may refer to official diplomatic communication, withdrawal or expulsion of diplomatic representation, or various economic sanctions. ${ }^{69}$ In addition to these traditional categories, 'rectification' has been recently as a sub-set of self-help. 70

The doctrine of self-help may be found in the Corfu Channel Case. This case was brought to the ICJ by the United Kingdom in order to resolve a dispute with Albania regarding the minesweeping operation. Right after the exchange of notes between the British and Albania on the right of innocent passage along the Corfu channel, on October 22, 1946, the United Kingdom dispatched a squadron of warships (two cruisers

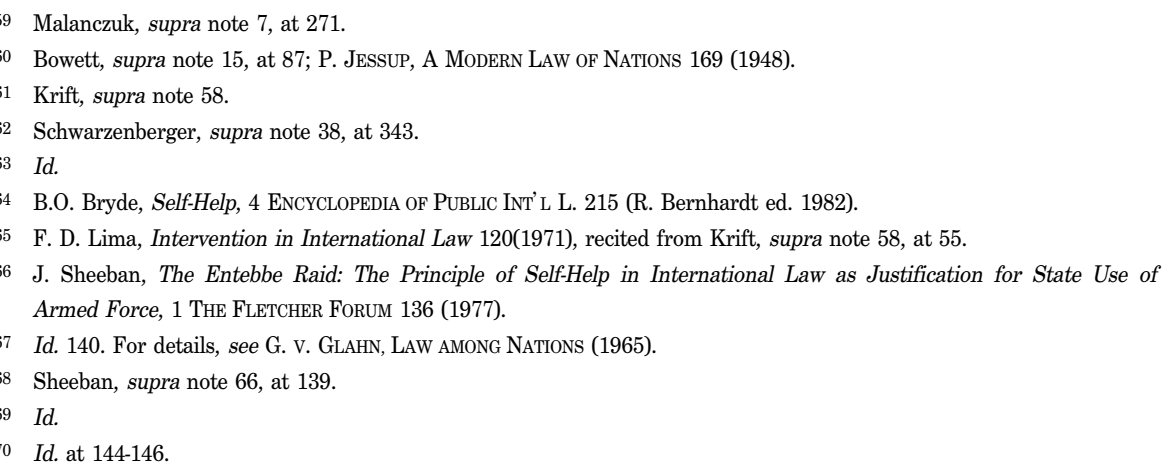


and two destroyers) to the Corfu channel.71 In the North Corfu Strait, the two destroyers were heavily damaged by mine-striking with ensuing death and injuries among the naval personnel.72 Less than a month later, on November 13, 1946, the British Navy's minesweeping operation was unilaterally undertaken in the Corfu channel. As Albania severely protested against it,73 the United Kingdom instituted proceedings against Albania before the ICJ.

The ICJ held Albania responsible for certain explosions on October 22, 1946 in Albanian waters and for the damage and loss of human life resulting from it. In its judgment, the Court stated that: "The minefield which had caused the damage and losses had been recently laid and that the factual evidence made it improbable that the Albanian authorities had been unaware of this mine-laying in Albanian waters." 74 The Court also held that: "The United Kingdom had not violated Albania's sovereignty by its action of October 22, 1946." 75 Simultaneously, the Court adjudicated that the minesweeping operation of the British Navy in Albanian waters of November 13, 1946 had violated the Albanian territorial sovereignty. ${ }^{76}$ In this case, the British did not charge Albania with an armed attack but with failure to remove the dangerous mines. The mine-sweeping was said to be a self-help measure to obtain evidence to support the British claim for damages and therefore as an aid in administering justice.77 The Court, however, rejected the British argument that the operation was to be classified into 'selfhelp.' It declared that:

\begin{abstract}
Between independent States, respect for territorial sovereignty is an essential foundation of international relations. The Court recognizes that the Albanian Government's complete failure to carry out its duties after the explosions, and the dilatory nature of its diplomatic notes, are extenuating circumstances for the action of the United Kingdom Government... [t]he Court must declare that the action of the British Navy constituted a violation of Albanian sovereignty.78
\end{abstract}

As mentioned above, customary international law has recognized the use of force for the protection of nationals abroad under limited conditions 'lawful' as an inherent right of a sovereign State. This kind of intervention may be categorized as either self-

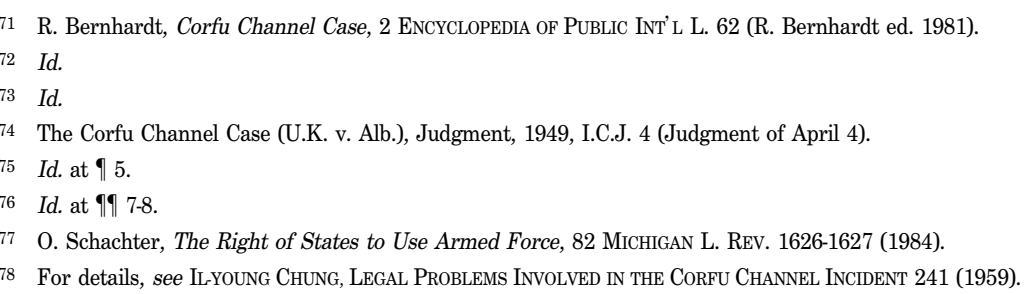


defense or self-help. Both seem similar in actual international dispute settlement process because they are exceptions to the prohibition of use of force in international relations. Also, self-help is an extension of self-defense. ${ }^{79}$ However, differences can be found between them. First, self-defense is an instant measure against present armed attack, while self-help is a secondary right of a State after a wrongdoing has been already committed. Second, self-defense is a response of a State against the other State, while self-help is a forcible measure to what is "not attributable to State." Third, self-defense can be justified under Article 51 of the UN Charter, while self-help has been recognized as legitimate under customary international law. 80

Table IV-1: Differences between Self-Defense and Self-Help

\begin{tabular}{|c|l|l|}
\hline \multicolumn{1}{|c|}{ Self-Defense } & \multicolumn{1}{c|}{ Self-Help } \\
\hline Timing & $\begin{array}{l}\text { Instant measure against present } \\
\text { armed attack }\end{array}$ & $\begin{array}{l}\text { Secondary Right of a State after a } \\
\text { wrong has been already committed }\end{array}$ \\
\hline Subject & State vs. State & State vs. Private Group \\
\hline Legal Basis & Article 51 of the UN Charter & Customary International Law \\
\hline
\end{tabular}

Source: Compiled by the author

\section{Conditions of Self-Help to be Legitimate}

The Korean Navy's rescue operation would be regarded as rather self-help than selfdefense basically on the grounds that: (1) the operation was undertaken six days after the Somali pirates had abducted the ship; and (2) the pirates are not involved in any government. In actual situation, however, some more conditions should be provided for the "Daybreak in the Gulf of Aden" operation to meet the legitimate threshold as a 'self-help.' In addition to general three basic principles such as necessity, proportionality, and lack of other means, more detailed terms have been presented by the following international lawyers.

Ronzitti presented six conditions as follows: (1) the intervention should not be

Krift, supra note 58, at 55-56; Bowett, supra note 15, at 91-94.

80 Doctrine of 'forcible self-help' has been developed by new rules beginning with the Covenant of the League of Nations in 1920. For details on the development of customary international law on self-help doctrine, see D. Gordon, Use of Force for the Protection of Nationals Abroad: The Entebbe Incident, 9 CASE W. RES. J. INT' L L. 118-122 (1977). 
punitive; (2) failure or inability of the local government to give required protection; (3) the intervention should be limited in time and space; (4) the violence is against the minimum rule of standard in international community; (5) no way to rescue the nationals abroad by another measure but the use of force; and (6) not in the course of international judicial proceeding. ${ }^{81}$

Lillich suggested five criteria where forcible self-help can be justified as follows. (1) Immediacy of violation of human rights: When the danger to the individuals concerned is imminent and the State responsible is unable or unwilling to protect them, forcible self-help is permissible.82 (2) Extent of violation of human rights: Forcible self-help is permissible only when fundamental human rights is substantially deprived and threatened.83 (3) Invitation to use forcible self-help: Forcible self-help may be constituted without special request of de jure government of a State.84 (4) Degree of coercive measures employed: The State asserting the right may employ only the amount of troops reasonably calculated to accomplish the objective and withdraw them when their mission is completed. 85 (5) Relative disinterestedness of acting state: A State only resorts to force to protect its own nations. When foreign nationals are involved, other motives are present. 86

Waldock also suggested three conditions for the lawful exercise of the right of selfhelp as follows: (1) an imminent threat of injury to nationals; (2) a failure or inability on the part of the territorial sovereign to protect them; and (3) measures of protection should be strictly confined to the object of protecting them against injury. 87

\section{B. The Case Analysis of Military Rescue Operations for National Hostages Abroad}

\section{Controversial Cases}

a. Israel's Entebbe Raid

On June 27, 1976, six hijackers claiming to be members of the Popular Front for the Liberation of Palestine skyjacked an Air France jetliner with 256 passengers and 12

\footnotetext{
81 N. Ronzitti, Rescuing Nationals Abroad through Military Coercion and Intervention on Grounds of Humanity 6972 (1985). See also Y. Shiryaev, The Right of Amed Self-Defense in International Law and Self-Defense Arguments Used in the Second Lebanon War, 3 ACTA SociETATIS AARTENSIS 86 (2007/2008).

82 Lillich, supra note 11, at 347.

83 Id. 348. For details, see M. McDougal \& F. Feliciano, LaW and Minimum World Public Order 208, n. 193 (1961).

84 Lillich, supra note 11, at 349.

85 Id. $349-350$.

86 Id. 350.

87 C. Waldock, The Regulation of the Use of Force by Individual States in International Law, 81 RecuEIL Des CouRS 467(1952-II).
} 
crewmen, en route from Tel Aviv to Paris after taking off from a stopover at Athens. The next day, the airplane, after stopping in Tripoli and Bengasi, finally landed in Entebbe, Uganda. 88 On June 29, the hijackers demanded 53 political prisoners detained in various parts of the world be freed in exchange for the release of the hostages. On June 30 and July 1, 147 non-Israeli passengers were released in two groups. During the negotiation, on July 4, Israeli airborne commandos raided Entebbe airport and freed all the hostages. 89 This is one of the most recent and striking cases of military rescue operation undertaken by a State to protect the lives of its national hostages abroad.

The Ugandan government strongly denounced Israel's derogation of its territorial sovereignty in the assault. The Security Council considered the matter at five meetings held between 7 and 17 of July, 1976.90 At the 1939th meeting of the Security Council held on July 9, 1976, Mr. Herzog, the Israeli representative released the Israeli positions in this case from an international legal perspective. ${ }^{91}$ They are summarized as follows:

Herzog emphasized the hijacking the Air France jetliner was "piracy and terrorism which threatens the very foundations of human society." He regarded himself as "accuser of the forces of evil." 92 Herzog insisted "Israel Defence Forces...rescued the hostages and escorted them to safety" because there was no alternative left for Israel.93 He continued to maintain that: "Uganda violated a basic tenet of international law in failing to protect foreign nationals on its territory. Furthermore, it behaved in a manner which constituted a gross violation of [Articles 6 and 9 of] ${ }^{94}$ the 1970 Hague Convention on the Suppression or Unlawful Seizure of Aircraft." 95 Herzog observed at considerable length some scholastic work of famous international lawyers in order to prove that "the weight of international law and precedent lie fully in Israel's favour" and also what Israel did should be legal based on "all that is moral on the earth." 96 Herzog referred to the statements of D.W. Bowet's Self-Defence in International Law. 97

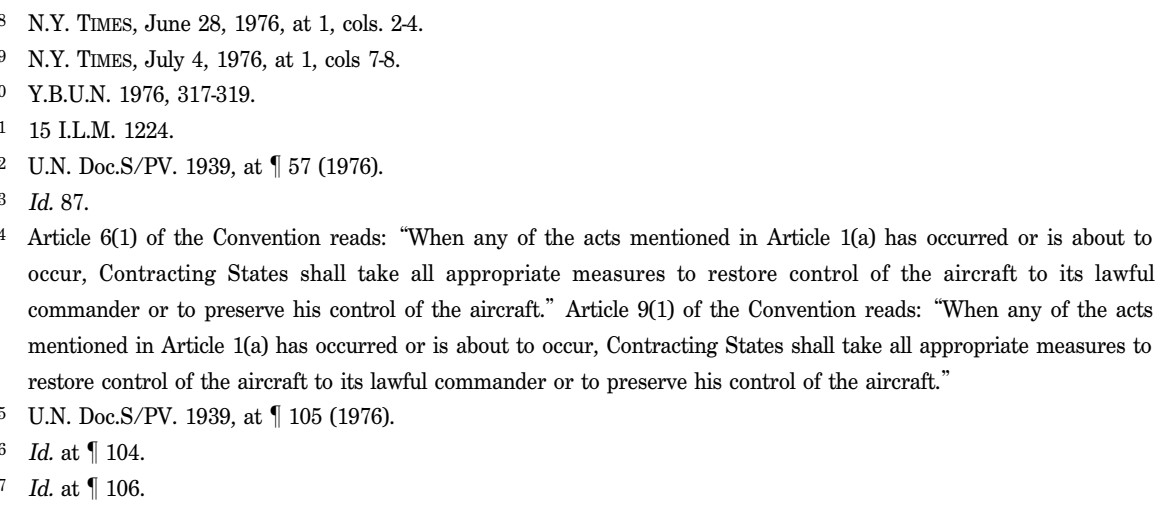

Article 6(1) of the Convention reads: "When any of the acts mentioned in Article 1(a) has occurred or is about to occur, Contracting States shall take all appropriate measures to restore control of the aircraft to its lawful commander or to preserve his control of the aircraft." Article 9(1) of the Convention reads: "When any of the acts mentioned in Article 1(a) has occurred or is about to occur, Contracting States shall take all appropriate measures to restore control of the aircraft to its lawful commander or to preserve his control of the aircraft." 
The right of the State to intervene by the use of threat of force for the protection of its nationals suffering injuries within the territory of another State is generally admitted, both in the writings of jurists and in the practice of States....In so far as this action takes effect in derogation of the sovereignty of the territorial State it must necessarily be exceptional in character and limited to those cases in which no other means of protection are available. 98

He also invoked the statements of J.L. Brierly's The Law of Nations.99

Cases of this form of intervention..., have generally been regarded as justified by the sheer necessity of instant action to save the lives of innocent nationals, whom the local government is unable or unwilling to protect. 100

In support of this contention, D.P.O' Connell's statement in his book, International Law was then cited. 101

Traditional international law has not prohibited States from protecting their nationals whose lives or property are imperiled by political conditions in another State... Article 2(4) should be interpreted as....not to prohibit a use of force which is limited in intention and effect to the protection of a state's own integrity and its nationals' vital interests. 102

Herzog continued to assert that: "The act of hijacking can well be regarded as one of piracy" against "enemies of the human race since the early days of international law." Certain norms were established in international law which permitted intervention...against [centres] of piracy... The principle of national sovereignty was overruled by the higher principles of man's liberty. $103 \mathrm{He}$ also stated that Israel's action in Entebbe was a "humanitarian rescue operation" according to "the higher law of human freedom," above which no national sovereignty can claim to be. Comparing it to the" rescuing innocent people from a holocaust against Hitler's sovereignty," 104 Herzog denied that the rescue operation was directed against Uganda or Ugandan sovereignty, but for its nationals from a band of terrorists and kidnappers who were being aided and abetted by the Ugandan authorities. 105 He finally asserted that Israel's rescue operation

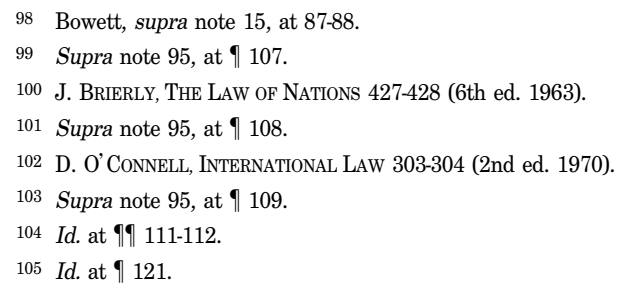


should be based on the highest values such as the dignity of man, human life and freedom which would lead to the struggle against international terrorism. 106

\section{b. The United States Rescue Operation for American Diplomatic Hostages in Teheran}

On November 4, 1979, a group of 'Muslim students' invaded the United States Embassy in Tehran and held the American hostages who were the diplomatic/consular staff and private citizens. The Iranian authorities did not intervene to impede the seizure and free the hostages. Even after thirteen people were released on November 18-19, more than fifty hostages were detained until January 20, 1981.107 Right after the attack on the Embassy, the UN Security Council regarded the matter as a grave threat to the international peace and security and passed a resolution on it.108 Together, the United States instituted proceedings against Iran before the International Court of Justice. The ICJ issued an order calling for the 'immediate release' of hostage.109 The United States also exerted pressure by increasing its unilateral action against Iran.110 Notwithstanding all attempts to liberalize the hostages by peaceful means the U.S. President Carter began considering the military rescue operation. During the night between April 24 and 25 of the same year, United States commandos landed in Tabas, Iran in order to reach Tehran and free the hostages. The operation (codename, Desert One) failed when a helicopter crashed into one of the C130 aircrafts and burst into flames. Eight soldiers died, and another four men suffered burns. 111

President Carter stated that this rescue mission was ordered "in order to safeguard American lives" and motivated not by Iran or the Iranian people, but by 'humanitarian aims.' 112 The Secretary of Defense H. Brown also characterized this not as a 'military action,' but as a 'rescue operation.' 113 Conversely, Iran violently condemned the raid as "blatant act of invasion." 114

The reaction of third States varied on the rescue operation. The United Kingdom argued that the U.S. rescue operation should be lawful as the amount of force and

\footnotetext{
106 Id. at 9 133, 138.

107 Ronzitti, supra note 81 , at 42.

108 S.C. Res. 475, U.N. Doc. S/Res. 475 (Dec. 4, 1979).

109 See United States Diplomatic and Consular Staff in Teheran (Iran v. U.S.), Provisional Measures, 1979 I.C.J., 21 (Dec. 15).

110 Ronzitti, supra note 81 , at 43.

111 See Tehran Hostage Rescue Mission Fails, BBC On This Day, Apr. 25, 1980, available at http://news.bbc.co.uk/onthisday/hi/dates/stories/april/25/newsid_2503000/2503899.stm (last visited on Feb. 10, 2012).

112 The Department of State Bulletin, vol. 80(1980), no. 2039, at 38.

113 Id. at 41.

114 N.Y. Times, Apr. 26, 1980, A.10.
} 
means deployed were necessary in order to free the hostages. Ian Gilmour said: "A military action,..., would require a considerable deployment of force to form a blockade or lay mines." 115 Most of the States in the western bloc maintained a similar position.116 However, the States in the socialist bloc, Middle East and Third Word criticized the operation. The Soviet news agency reported: "The United States had infringed international law." China declared that the attempt to release the U.S. hostages was a violation of Iranian territorial integrity. Pakistan said the operation amounted to a grave violation of Iranian sovereignty. 117 Noticeable is that Italy had an ambiguous position. The Ministry of Foreign Affairs stated: "Italian opinion has always, in every circumstance, been contrary to the use of force in freeing hostages." Later, however, the Italian government agreed that the U.S. action was lawful.118

The Security Council did not adopt any resolution regarding the U.S. rescue operation. The ICJ pointed out that it was not in a position to settle either the question of "legality of the operation of 24 April 1980, under the Charter of the United Nations and under general international law," or "any possible question of responsibility flowing from it." 119 The Court only mentioned it because the raid took place while the case was being adjudicated. There is still a controversy whether a military rescue operation for the hostages detained in a foreign country would be lawful while peaceful resolution process is being processed.

\section{Uncontroversial Cases}

\section{a. German Rescue Operation in Mogadishu}

On October 13, 1977, a Lufthansa Boeing 737 flight which took off from Palma de Mallorca en route to Frankfurt with 86 passengers and 5 crews was hijacked over Marseilles by four militants calling themselves "Commando Martyr Halime." The hijackers demanded the release of 10 Red Army Faction ("RAF") terrorists detained at the JVA Stuttgart-Stammheim prison plus two Palestinian compatriots held in Turkey and USD15million. 120 After stopping over at several airports including Rome, Cyprus, Bahrain, Dubai, Aden, the Lufthansa airplane finally landed at Mogadishu, Somalia. On October 18, 1977, a German counter-terrorism commando unit, GSG9 stormed the plane

\footnotetext{
115 Ronzitti, supra note 81 , at 46.

116 Id. at 47.

117 See The Times, Apr. 26, 1980, at 5-6; N.Y. Times, Apr. 26, 1980, A10; Le MonDE, avril 27-28, 1980, at 4.

118 Ronzitti, supra note 81 , at 46.

119 See United States Diplomatic and Consular Staff in Tehran, Judgment, 1980 I.C.J. 43 (May 24).

120 See Germany Faces Tough Task in Controlling Terrorism Editorial(AP), available at http://www.baadermeinhof.com/wp-content/uploads/2011/11/10-26-1977-Germany-Faces-Tough-Task-in-Controlling-Terrorism-EditorialAP.pdf (last visited on Feb. 10, 2012).
} 
and rescued the hostages.121 The German rescue operation(codename, Fire Magic) did not raise any controversies regarding sovereignty because it was fully supported by the Somali government at that time.

\section{b. Indonesia's Woyla Rescue Operation in Bangkok in 1981}

On March 28, 1981, a Garuda Indonesian Airways flight 206 was hijacked by a number of Muslim terrorists en route from Jakarta to Medan, Indonesia. The hijackers demanded as follows: (1) the release of 80 commando Jihad members imprisoned in Indonesia; (2) USD 1.5 million; and (3) an airplane to take the prisoners. They ordered the pilot to fly the plane to Colombo, Sri Lanka. Since the plane did not have enough fuel, however, it refueled in Penang, Malaysia and then to Don Muang, Thailand. The hijackers threatened to blow up the plane if their demands were not met by 13:00 on March 30, 1981.122 In the early morning on March 31, a group of Indonesian Army Special Forces aided by Royal Thai Air Force commandos raided the plane and rescued the hostages. This rescue operation did not give raise to any particular problem regarding sovereignty because it was conducted with the consent and support of the Thai government. 123

\section{Conclusion}

In this paper, the author has analyzed the legal characteristics of the Korean Navy's military rescue operation for the hostages detained under the Somali pirates on January 21,2011 . The operation is basically "forcible protection of nationals abroad." It is categorized into 'self-help' rather than 'self-defense,' mainly because the navy's operation was directed against actions "not attributable to States." A critical point of contention is whether this navy's rescue operation was legitimate under international law in spite of the principle of the "prohibition of use of force," as laid down at Article 2(4) of the UN Charter. Another issue is whether such an operation could infringe the territorial integrity of other nations because the flag State of SAMHO Jewelry was not Korea.

The Korean Navy's rescue operation was based on legal grounds such as the

121 See Lufthansa Flight 181, WIKIPEDIA ENCYCLOPEDIA, available at http://en.wikipedia.org/wiki/Lufthansa_Flight_181 (last visited on Feb. 10, 2012). For details, see C. McNab \& H. Gerrard, Storming Flight 181 - GSG-9 and the Mogadishu HiJack 1977 (2011); B. Davis, Fire Magic: HiJack to Mogadishu (1994).

122 See A Brief Note about Kopassus, Indonesian Army Special Forces, available at http://indomil.wordpress.com/2009/ 06/06/a-brief-note-about-kopassus-indonesian-army-special-forces (last visited on Feb. 10, 2012).

123 Ronzitti, supra note 81 , at 81. 
UNCLOS, the Security Council's resolutions (Res. 1816-2020), and the International Convention against the Taking of Hostages. In addition, arguments from previous military rescue operations would help understand the Korean case better. At the 1941 st meeting of the Security Council over the legitimacy of the Entebbe raid of 1976, Mr. Scranton, the representative of the United States recognized the legitimacy of foreign intervention to protect nationals as follows:

Israel's action in rescuing the hostages necessarily involved a temporary breach of the territorial integrity of Uganda. Normally, such a breach would be impermissible under the Charter of the United Nations. However, there is a well established right to use limited force for the protection of one's own nationals from an imminent threat of injury or death... The right,..., is limited to such use of force as is necessary and appropriate to protect threatened nationals from injury. 124

He added: "The requirements of this right to protect nationals were clearly met in the Entebbe case. Israel had good reason to believe that at the time it acted Israeli nationals were in imminent danger of execution by the hijackers. Moreover, the actions necessary to release the Israeli nationals or to prevent substantial loss of Israeli lives had not been taken by the Government of Uganda, nor was there a reasonable expectation such actions would be taken." 125

Based on this "implicit recognition of the right to use of force" to intervene to protect its nationals provided the requisite conditions were met, the Korean Navy's rescue operation was "within the bound of State conduct permissible" under international law with the proper set of circumstances.126 [Emphasis added] The UN Charter does not abrogate a State's right to resort to self-help including the use of armed force under customary international law. The Charter simply suspends it since the Security Council is entrusted with the task of safeguarding the rights of member States in the first hand. 127

Inferring from the statements abovementioned, and other conditions that (1) Korean crewmen were the objects of protection; (2) humanitarian intervention in its full scope would not be available under a self-defense rationale; and (3) it undoubtedly would encourage the use of a greater degree of force,128 the Korean Navy's rescue operation shall be fully justified under international law as an act of forcible self-help and the

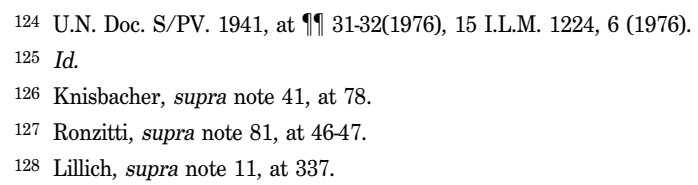


60 Eric Y.J.Lee

realization of an existing international legal right.129 Humanitarian considerations were taken for the foreign(Burmese and Indonesian) crewmen rescued together.

129 Fitzmaurice, supra note 14, at 172. 